\title{
CUSTOMS SECURITY IN THE EUROPEAN UNION - AUTHORISED ECONOMIC OPERATOR (AEO)
}

\section{BEZPIECZEŃSTWO CELNE W UNII EUROPEJSKIEJ - CERTYFIKAT UPOWAŻNIONEGO PRZEDSIEBIORCY (AEO)}

\author{
Edyta Janowska-Bucka \\ Silesian University of Technology, Faculty of Transport, \\ Railway Engineering Department \\ Politechnika Śląska, Wydzial Transportu, Katedra Transportu Szynowego \\ 40-019 Katowice, ul. Krasińskiego 8 \\ e-mail: edyta.janowska-bucka@polsl.pl
}

\begin{abstract}
The $1^{\text {st }}$ January 2008 came into force the institution of an Authorised Economic Operator (abbreviation - AEO). By obtaining an AEO certificate, the Authorised Economic Operator becomes reliable in the European Community in the field of its customs operations and has right to take benefit because of this.
\end{abstract}

Keywords: safety, customs security, supply chain

Streszczenie. Z dniem 1 stycznia 2008 roku weszła w życie instytucja upoważnionego przedsiębiorcy (Authorised Economic Operator, dalej w skrócie AEO). Po uzyskaniu świadectwa AEO upoważniony przedsiębiorca jest wiarygodny we Wspólnocie Europejskiej w zakresie swoich operacji celnych i przysługuje mu prawo do uzyskania korzyści z tego powodu.

Slowa kluczowe: bezpieczeństwo, bezpieczeństwo celne, logistyczny łańcuch dostaw 


\section{CUSTOMS SECURITY IN THE EUROPEAN UNION - AUTHORISED ECONOMIC OPERATOR (AEO)}

\section{Introduction}

The institution of an Authorised Economic Operator (AEO) was established on the $1^{\text {st }}$ January 2008 which operates within a framework of the European Customs Security Programme in the logistic supply chain. From this date entrepreneurs, who are interested in gaining a status of AEO, can submit an application for issuing of the AEO certificate to the customs bodies. When they gain this certificate they can make use of facilities connected with the customs control in the field of security and protection and/or reductions for customs regulations.

Global terrorism and in particular the events in New York (11.09.2001), Madrid (11.03.2004) and London (07.07.2005) were the reason why changes in customs regulation concerning security were made. To prevent successive tragedies the World Customs Organization (WCO) has prepared customs security standards and on the 105/106 WCO session (July 2005) "Framework of standards to secure and facilitate global trade" document was accepted. The European Union, going ahead appeared needs, also has aggravated security and protection standards. Among other things this led to an introduction of the AEO status [1].

\section{Stakeholders in an international supply chain}

In the international supply chain there are different economic operators, which create different segments of a trade sector (picture 1) [1]. From the analysis of this diagram results, it is clear that all the mentioned operators do not have to occur in each logistic supply chain. Often, among these operators, exist long-term trade relationships. In some cases, they can enter into mutual trade relations only for one shipment.

The operators have different obligations, which depend on their participation in the logistic supply chain. Guidelines regarding obligations of particular participants of the supply chain are included in TAXUD/2006/1450 from the $29^{\text {th }}$ of June 2007. 


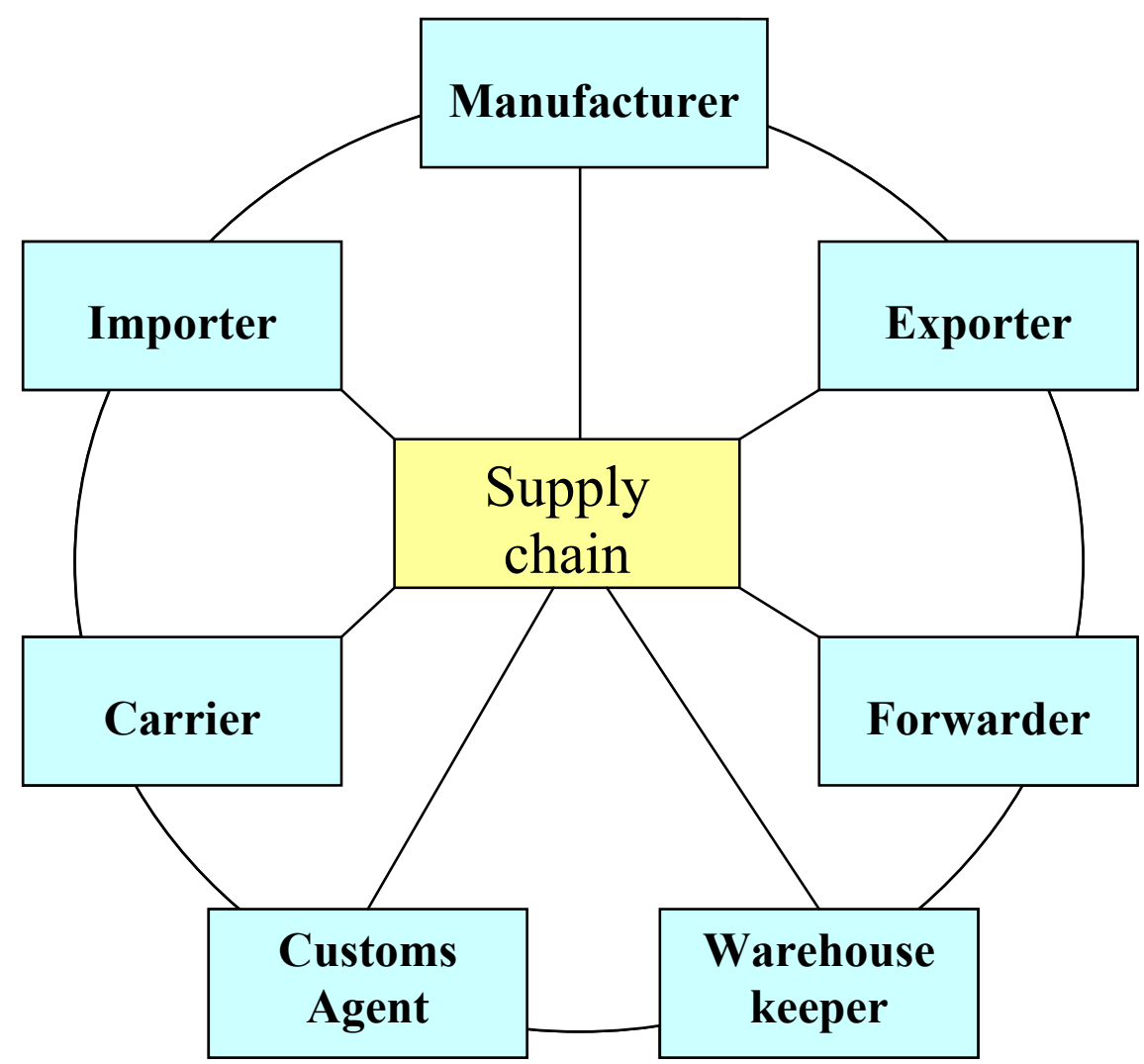

Pict.1. Supply chain.

\section{Function of the Authorised Economic Operator}

\subsection{Basic information about AEO}

The Institution of the the Authorised Economic Operator (AEO) was introduced in the legal system of the European Union by UE decree No $648 / 2005$ of the European Parliament and Council dated on the $13^{\text {th }}$ April 2005. Its use was possible only from the $1^{\text {st }}$ January 2008 after the implemented regulations came into force. These regulations were accepted the $18^{\text {th }}$ December 2006 by the European Commission decree No $1875 / 2006$ (Implementing regulation). 
The economic operator, who has the AEO certificate, is reliable in the European Community in the field of its customs operations and has right to take benefits, for example: a lower number of physical controls and documents' controls (unless other European regulations recommend a regular number of controls).

It can have one of the AEO certificates, which are mentioned in the article 14 a of the Implementing Regulation :

1. The AEO certificate - Customs Facilitations guarantees easier access to customs simplifications;

2. The AEO certificate - Security and Protection entitles its owner to reach facilitations in the field of security and protection control;

3. The AEO certificate - Customs Facilitations/Security and Protection links benefits of the above mentioned kinds of certificates.

The status of AEO can be given to each entrepreneur, who has office in the European Union (exceptions are defined by rules of the Implementing Regulation). He must fulfill conditions and criteria, which are named in the article 5a of Act No 2 of the Customs Community Code. There are [2]:

- an appropriate record of compliance with customs requirements;

- a satisfactory system of managing commercial and, where appropriate, transport records, which allows appropriate customs controls;

- proven financial solvency;

- appropriate security and safety standards.

The above mentioned requirements and criteria were presented in detail in the article $14 \mathrm{~h}-14 \mathrm{k}$ of the Implementing regulation.

\subsection{Making an application}

The status of the Authorised Economic Operator is given on application of a participant of the logistic supply chain. An example of application is defined in annex $1 \mathrm{C}$ to the above mentioned Implementing Regulation. The following should be submitted with the application:

a) a confirmation of running an economic activity by the applicant, as well as having a head office in the customs area of the community;

b) a confirmation of fulfillment of the formal requirements;

c) a questionnaire of AEO self-evaluation.

In most cases only one member of a state country will deal with the application for the AEO status. It will be the country, where the books and customs formalities are led. In cases, where the books are kept in one member state, and customs formalities are made in other one, the 
application should be submited in the place, where the books are kept. Article $14 \mathrm{~d}$ of Act No 1-3 of the Implementing regulation resolved that [3]:

1. The application shall be submitted to one of the following customs authorities:

a) the customs authority of the Member State where the applicant's main accounts related to the customs arrangements involved are held, and where at least a part of the operations to be covered by the AEO certificate are conducted;

b) the customs authority of the Member State where the applicant's main accounts related to the customs arrangements involved are accessible in the applicant's computer system by the competent customs authority using the information technology and computer networks, and where the applicant's general logistical management activities are conducted, and where at least part of the operations to be covered by the AEO certificate are carried out.

2. If the competent customs authority can not be determined under paragraph 1, the application shall be submitted to the customs authority of the Member State where the applicant's main accounts related to the customs arrangements involved are accessible, as referred to in paragraph 1b), and the applicant's general logistical management activities are conducted.

An applicant's main accounts referred to in points a) and b) shall include records and documentation which would enable the customs authority verification and monitoring of the conditions and the criteria necessary for obtaining the AEO certificate.

In Poland there are three Customs Chambers - in Szczecin, Warszawa and Wrocław, which accept applications and issue the AEO certificate. Customs Chamber in Wrocław realizes international consultation procedure in relation to allowing AEO certificate. Picture 2 [4] shows the area on which Customs Chambers operate.

The economic operator, who received the AEO certificate, will be subjected to periodical audit that controls fulfillment of the AEO criteria. These audits will be realized at the least once every three years. 


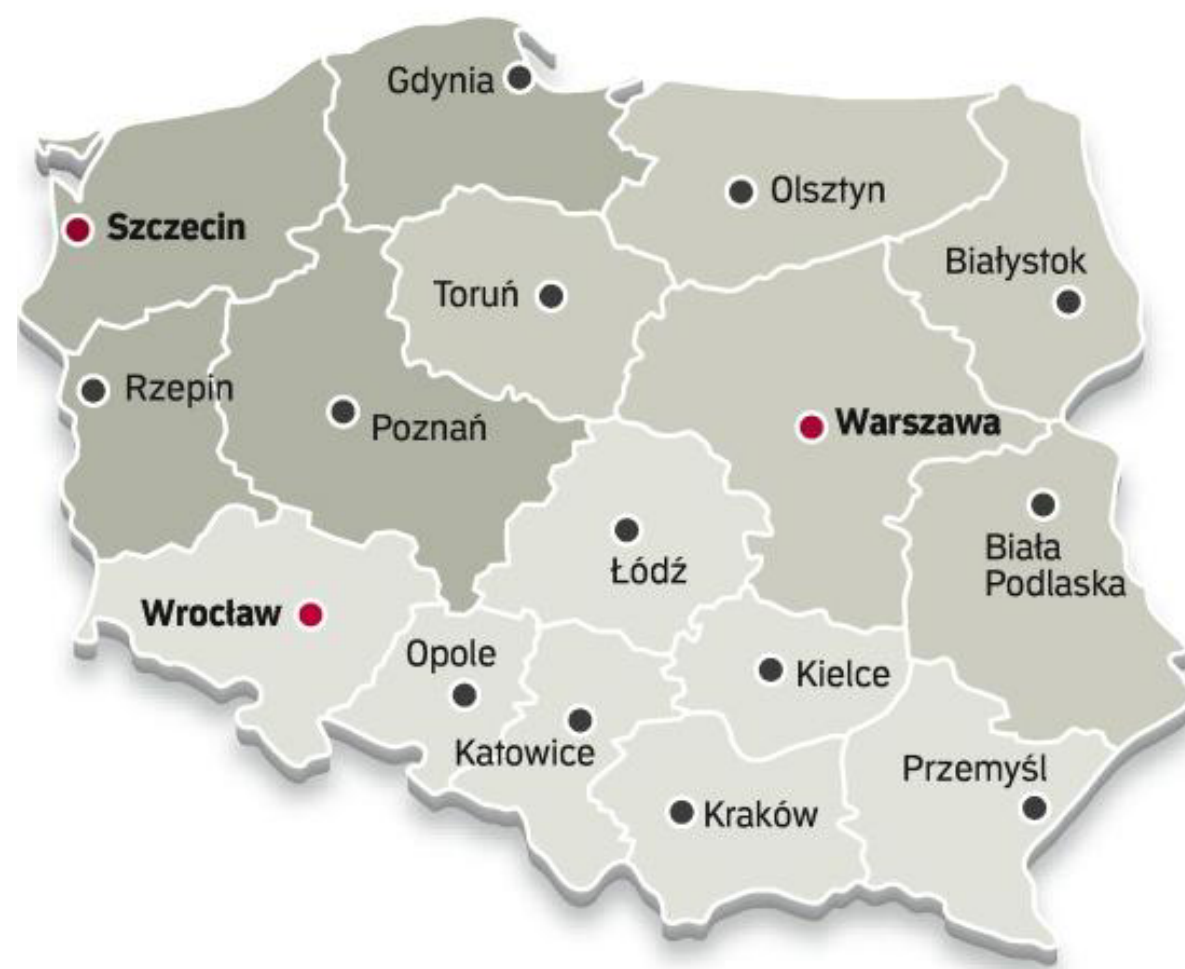

Pict. 2. Reach of action appointed Customs Chambers in Poland

\subsection{Advantages of the AEO certificate}

The status of the AEO of a EU member state country will be respected in the whole Community.

The status of AEO entitles to use facilitations connected with the customs control in the field of security and protection and/or reductions provided for the customs regulations. Benefits result from the status of AEO are named in the Implementing Regulation. They depend on a kind of certificate.

Each AEO owner will have the following benefits:

- Will be subjected to a smaller number of physical control and documents' control than other entrepreneurs;

- in the case of control it will be given priority;

- on the AEO application, it is possible to be controlled outside customs' office.

Every owner of the AEO certificate of Security and Protection, as well as the AEO simplifications - Security and Protection will:

- have a possibility to submit less data in a declaration before the transport or export of goods; 
- in the case that a consignment they will be chosen to control on the basis of a declaration before the export and import of goods, customs bodies can earlier inform the authorised operator.

Additionally, owners of the AEO certificate - Security and Protection as well as the AEO simplifications - Security and Protection, after concluding appropriate agreements by the European Community, will use recognized certificates and benefits result from them in the third countries.

It is planned to introduce an electric information and communication system of AEO. This system will keep the following information:

- data concerning applications transmit via electronic way;

- AEO certificates as well as, in proper case, changes, suspensions and removals of certificates;

- all other significant information;

- data base of the people having the status of AEO - accessible for all.

\section{How AEO can improve security of supply chain .}

Authorised Economic Operators can only be held responsible for their part of the supply chain, for the goods which are under their custody and for the facilities they operate. However, they are also dependent on the security standards of their business partners.

In order to meet the requirement AEOs should, when entering into new contractual arrangements with a business partner encourage the other contracting party to assess and enhance their supply chain security. In addition, the AEO is recommended to retain documentation in support of this aspect to demonstrate their efforts to ensure that their business partners meet these requirements - it is planned to introduce Safety Declaration for companies which don't have AEO status. The AEO could also review relevant commercial information relating to the other contracting party before entering into trade relations.

Whenever the AEO has information that one of his business partners, who is a part of the international supply chain, does not establish appropriate security and safety standards, he will immediately take appropriate measures, to the possible extent, to enhance supply chain security.

Regarding consignments taken over from unknown business partners: it is recommended that the AEO takes measures to guarantee that security risks related to unknown business partners can be limited to an acceptable level. In case the AEO discovers compliance difficulties, it shall inform the customs authorities about such occurrences. 


\section{Conclusion}

Investments made by the economic operators in order to improve their security and protection standards - in connection with a willingness to own the status of AEO - can cause positive effects in the following fields:

- a control on a flow of goods from a manufacturer to a consumer ("visibility and tracking");

- an elaboration of proceeding procedures;

- a bigger commitment of employees in procedures;

- a selection of suppliers and investments;

- a safety of transport and carriage;

- a building of organizational infrastructure conscience;

- a cooperation among parties of a supply chain;

- active technological investments as well as a voluntary warnings of security requirements;

- a decrease of a number of accidents connected with security and protection;

- an improvement of security and communication among partners in the supply chain.

Because 2 years period of transition was introduced $(01.01 .2008$ 31.12.2009), in which time of waiting for consideration of an application was prolonged to 300 calendar days, at the moment of writing of the article the information about any economic operator having the status of AEO in Poland was not found. Further observation of the AEO certification proceedings as well as resulting profits is advisable.

\section{Literature}

1. Janowska-Bucka E.: Program bezpieczeństwa celnego w logistycznym tańcuchu dostaw - certyfikat AEO (Authorised Economic Operator). Materiały z konferencji „Efektywny transport - konkurencyjna gospodarka" Akademia Ekonomiczna w Katowicach - w druku.

2. Rozporzadzenie (WE) $n r$ 648/2005 Parlamentu Europejskiego i Rady z dnia 13 kwietnia 2005r. zmieniajace rozporzadzenie Rady (EWG) $n r$ 2913/92 ustanawiajace Wspólnotowy Kodeks Celny (Dz. Urz. UE L117 z 4.05.2005, s. 13).

3. Rozporzqdzenie Komisji (WE) $n r \quad 1875 / 2006$ zmieniajace rozporzadzenie (EWG) $n r$ 2454/93 ustanawiajace przepisy $w$ celu wykonania Wspólnotowego Kodeksu Celnego (Dz. Urz. WE L 360 z 19.12.2006 str. 64).

4. www.rp.pl/galeria/1,77650.html 


\section{BEZPIECZEŃSTWO CELNE W UNII EUROPEJSKIEJ - CERTYFIKAT UPOWAŻNIONEGO PRZEDSIEBIORCY (AEO)}

\section{Wstęp}

W ramach Europejskiego Programu Bezpieczeństwa Celnego w logistycznym łańcuchu dostaw została powołana z dniem 1 stycznia 2008 roku instytucja „upoważnionego przedsiębiorcy” (Authorised Economic Operator, dalej w skrócie AEO). Z tą datą przedsiębiorcy zainteresowani uzyskaniem statusu AEO mogą składać do organów celnych wnioski o wydanie świadectwa AEO, a po jego uzyskaniu korzystać z ułatwień odnoszących się do kontroli celnej dotyczącej bezpieczeństwa i ochrony i/lub z uproszczeń przewidzianych w ramach przepisów celnych.

Genezą zmian w przepisach celnych dotyczących bezpieczeństwa był światowy terroryzm, a w szczególności wydarzenia w Nowym Jorku (11.09.2001), Madrycie (11.03.2004) i Londynie (07.07.2005). Chcąc zapobiec kolejnym tragediom Światowa Organizacja Ceł (WCO) przygotowała standardy bezpieczeństwa celnego i na 105/106 Sesji WCO w lipcu 2005 roku przyjęła dokument „Zarys Standardów dla Bezpieczeństwa i Ułatwień w Handlu Międzynarodowym" (Framework of standards to secure and facititate global trade). Również Unia Europejska wychodząc naprzeciw zaistniałym potrzebom zaostrzyła standardy bezpieczeństwa i ochrony a zaowocowało to między innymi wprowadzeniem statusu upoważnionego przedsiębiorcy AEO [1].

\section{Zainteresowane strony}

Międzynarodowy logistyczny łańcuch dostaw składa się z szeregu podmiotów gospodarczych, które tworzą różne segmenty sektora handlu (rys.1.) [1]. Z analizy tego rysunku wynika, że nie w każdym logistycznym łańcuchu dostaw muszą występować wszystkie wymienione podmioty. Często między tymi podmiotami istnieją długotrwałe stosunki handlowe, w niektórych wypadkach jednak wzajemne stosunki handlowe mogą być nawiązywane tylko na potrzeby jednej wysyłki. 
Podmioty posiadają różne obowiązki zależnie od ich udziału w logistycznym łańcuchu dostaw. Wytyczne odnośnie obowiązków poszczególnych uczestników łańcucha dostaw znajdują się $\mathrm{w}$ dokumencie TAXUD/2006/1450 z dn. 29 czerwca 2007.

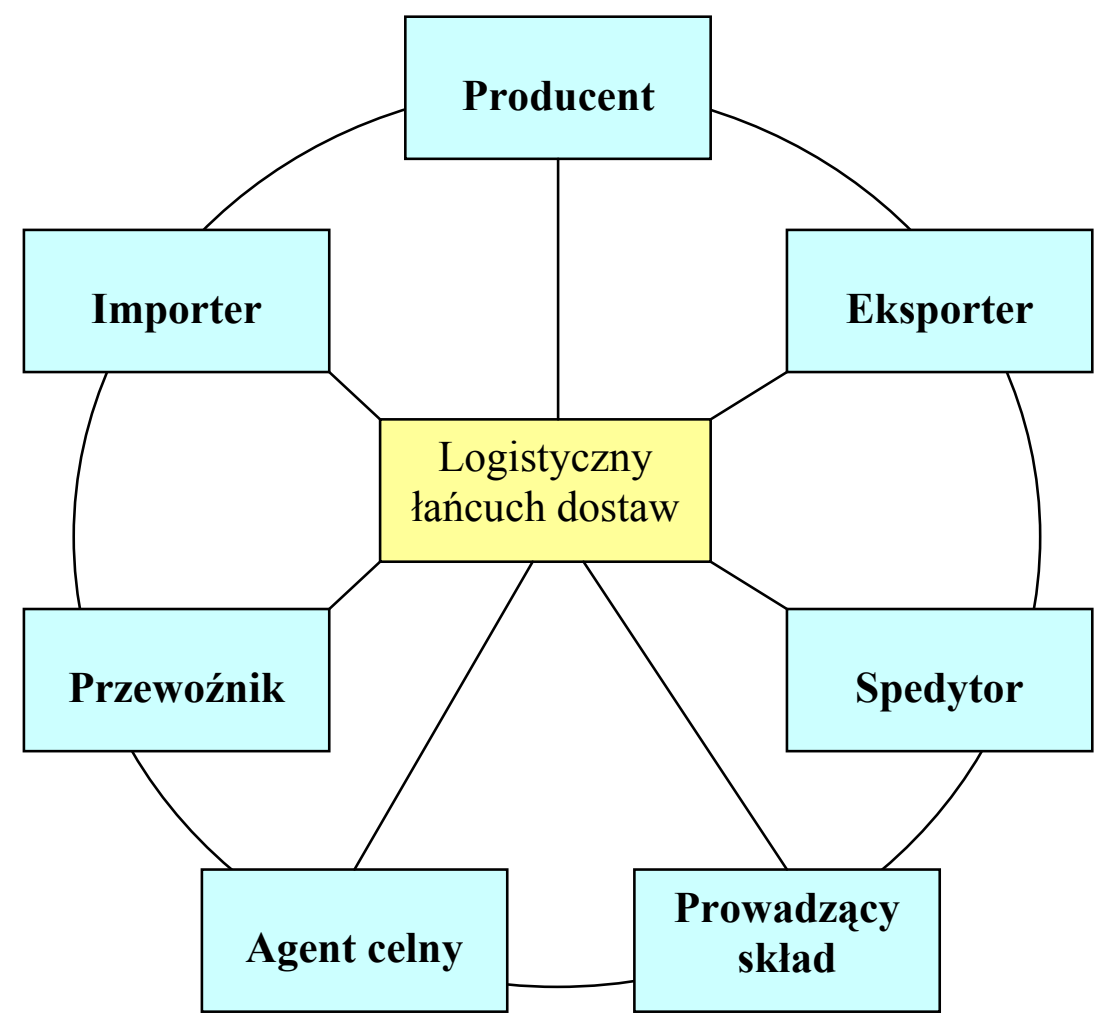

Rys.1. Logistyczny łańcuch dostaw.

\section{Funkcja upoważnionego przedsiębiorcy - AEO}

\subsection{Podstawowe informacje o AEO}

Instytucja upoważnionego przedsiębiorcy (AEO) została wprowadzona do porządku prawnego Unii Europejskiej rozporządzeniem (WE) nr 648/2005 Parlamentu Europejskiego i Rady z dnia 13 kwietnia 2005r., z tym, że jej zastosowanie było możliwe dopiero od 1 stycznia 2008r. po wejściu w życie przepisów wykonawczych przyjętych w dniu 18 grudnia 2006r. rozporządzeniem Komisji (WE) nr 1875/2006 (Rozporządzenie Wykonawcze). 
Po uzyskaniu świadectwa AEO upoważniony przedsiębiorca jest wiarygodny we Wspólnocie Europejskiej w zakresie swoich operacji celnych i przysługuje mu prawo do uzyskania korzyści z tego powodu takich jak m.in. mniejsza liczba kontroli fizycznych i kontroli dokumentów (chyba że inne przepisy wspólnotowe zalecą stałą liczbę takich kontroli). Może on posiadać jedno ze świadectw AEO, o którym mowa w art. 14a Rozporządzenia Wykonawczego:

1. Świadectwo AEO - Uproszczenia Celne zapewnia łatwiejszy dostęp do uproszczeń celnych;

2. Świadectwo AEO - Bezpieczeństwo i Ochrona uprawnia jego posiadacza do uzyskania ułatwień $\mathrm{w}$ zakresie kontroli bezpieczeństwa i ochrony;

3. Świadectwo AEO - Uproszczenia Celne/Bezpieczeństwo i Ochrona łączy w sobie korzyści dwóch wcześniej wymienionych rodzajów świadectw.

Status AEO może zostać udzielony każdemu przedsiębiorcy posiadającemu siedzibę na obszarze Wspólnoty (wyjątki określają przepisy Rozporządzenia Wykonawczego) spełniającemu warunki i kryteria, o których mowa w art. 5a ust. 2 Wspólnotowego Kodeksu Celnego. Są to [2]:

- odpowiednie przestrzeganie wymogów celnych;

- odpowiedni system zarządzania ewidencjami handlowymi i, gdzie zachodzi taka potrzeba, ewidencjami transportowymi, który umożliwia właściwą kontrolę celną;

- udokumentowana wypłacalność;

- odpowiednie standardy bezpieczeństwa i ochrony.

Powyższe warunki i kryteria zostały szczegółowo rozpisane w art. 14h $\div$ 14k Rozporządzenia Wykonawczego (WE).

\subsection{Sktadanie wniosków}

Status upoważnionego przedsiębiorcy udzielany jest na wniosek uczestnika logistycznego łańcucha dostaw. Wzór wniosku określony został w załączniku 1C do wymienionego wcześniej Rozporządzenia Wykonawczego. Wraz z wnioskiem należy złożyć:

a) potwierdzenie prowadzenia przez wnioskodawcę działalności gospodarczej oraz posiadania siedziby na obszarze celnym Wspólnoty;

b) potwierdzenie spełnienia wymogów formalnych;

c) kwestionariusz samooceny AEO. 
W większości przypadków wnioskiem o przyznanie statusu AEO będzie zajmować się tylko jedno państwo członkowskie UE - to, w którym prowadzone są księgi rachunkowe i prowadzone formalności celne. W przypadkach, gdy główne księgi rachunkowe są utrzymywane w jednym państwie członkowskim, a formalności celne prowadzone są $\mathrm{w}$ innym państwie członkowskim, wniosek musi zostać złożony tam, gdzie utrzymywane są główne księgi rachunkowe. Artykuł 14d ust. 1-3 przepisów wykonawczych stanowi, że [3]:

1. Wniosek składa się do jednego z następujących organów celnych:

a) organu celnego państwa członkowskiego, w którym prowadzone są główne księgi rachunkowe wnioskodawcy dotyczące odnośnych procedur celnych, oraz $\mathrm{w}$ którym prowadzona jest przynajmniej część operacji, które mają być objęte świadectwem AEO;

b) organu celnego państwa członkowskiego, w którym główne księgi rachunkowe wnioskodawcy dotyczące odnośnych procedur celnych są dostępne w systemie komputerowym wnioskodawcy dla właściwego organu celnego przy użyciu technik informatycznych oraz sieci komputerowych, i w którym prowadzone są ogólne działania logistyczne wnioskodawcy oraz w którym prowadzona jest przynajmniej część operacji, które mają być objęte świadectwem AEO.

2. Jeżeli właściwego organu celnego nie da się ustalić na podstawie ust. 1, wniosek składa się do organu celnego państwa członkowskiego, w którym główne księgi rachunkowe dotyczące procedur celnych są prowadzone lub w którym są one dostępne, jak określono w ust. 1 lit b); w tym ostatnim przypadku ogólne działania logistyczne wnioskodawcy muszą być prowadzone w tym samym państwie członkowskim.

Główne księgi rachunkowe wnioskodawcy, o których mowa w pkt 1a) i 1b) powyżej, obejmują zapisy i dokumentację umożliwiającą organowi celnemu zweryfikowanie i monitorowanie warunków i kryteriów niezbędnych do uzyskania świadectwa AEO.

W Polsce do przyjmowania wniosków i wydawania świadectw AEO wyznaczono trzy Izby Celne - w Szczecinie, Warszawie i Wrocławiu, przy czym Izba Celna we Wrocławiu została wyznaczona także do przeprowadzania międzynarodowej procedury konsultacyjnej. Zasięg działania w/w Izb Celnych ilustruje rys.2 [4].

Po otrzymaniu statusu AEO podmiot gospodarczy będzie podlegał okresowym audytom sprawdzającym spełnianie kryteriów AEO. Audyty te będą przeprowadzane co najmniej raz na trzy lata. 


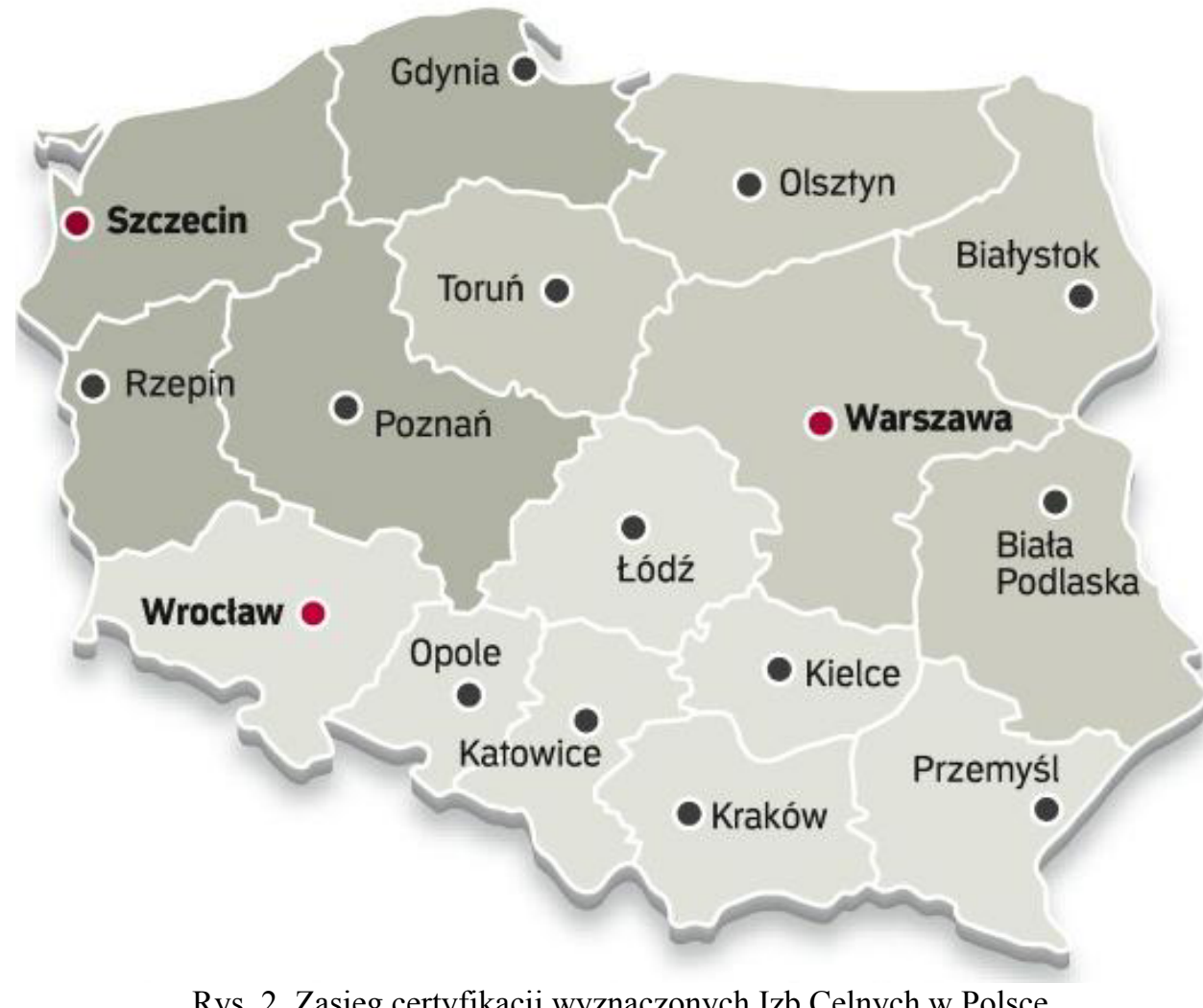

Rys. 2. Zasięg certyfikacji wyznaczonych Izb Celnych w Polsce

\subsection{Korzyści z posiadania certyfikatu AEO}

Status AEO przyznany w jednym państwie członkowskim Unii Europejskiej będzie uznawany w całej Wspólnocie.

Status AEO uprawnia do korzystania $\mathrm{z}$ ułatwień odnoszących się do kontroli celnej dotyczącej bezpieczeństwa i ochrony i/lub z uproszczeń przewidzianych $\mathrm{w}$ ramach przepisów celnych. Korzyści wynikające ze statusu AEO precyzuje Rozporządzenie Wykonawcze uzależniając je od rodzaju świadectwa.

Każdy posiadacz świadectwa AEO, korzysta z następujących ułatwień:

- będzie podlegał mniejszej niż inni przedsiębiorcy liczbie kontroli fizycznych i kontroli dokumentów;

- w przypadku wytypowania do kontroli będzie ona przeprowadzana w sposób priorytetowy;

- na wniosek AEO możliwe jest przeprowadzenie kontroli w miejscu innym niż urząd celny. 
Natomiast posiadacz Świadectwa AEO Bezpieczeństwo i Ochrona oraz AEO Uproszczenia/Bezpieczeństwo i Ochrona, z dniem 1 lipca 2009r., będzie korzystał z:

- możliwości składania mniejszego zakresu danych w deklaracji przed przywozem lub wywozem towarów;

- w przypadku wytypowania przesyłki do kontroli na podstawie deklaracji przed przywozem lub wywozem towarów organy celne mogą o tym wcześniej powiadomić upoważnionego przedsiębiorcę.

Dodatkowo posiadacze Świadectwa AEO Bezpieczeństwo i Ochrona oraz AEO Uproszczenia/Bezpieczeństwo i Ochrona, po zawarciu przez Wspólnotę Europejską odpowiednich porozumień, będą mogli korzystać z uznania świadectw i korzyści z nich wynikających w krajach trzecich.

Planowane jest wprowadzenie elektronicznego systemu informacyjnokomunikacyjnego AEO. System ten będzie przechowywał następujące informacje:

- dane dotyczące wniosków przekazywane drogą elektroniczną;

- świadectwa AEO oraz, w stosownych przypadkach, zmiany, zawieszenie i cofnięcie świadectw;

- wszelkie inne istotne informacje;

- baza danych osób posiadających status AEO - dostępna dla wszystkich.

\section{Jak AEO może poprawić bezpieczeństwo lańcucha dostaw}

Upoważnieni przedsiębiorcy AEO mogą odpowiadać wyłącznie za swoją część łańcucha dostaw, towary znajdujące się pod ich pieczą oraz instalacje, którymi dysponują. Jednakże są oni także uzależnieni od standardów bezpieczeństwa stosowanych przez ich partnerów handlowych.

W celu spełnienia wymagań przy wchodzeniu w nowe stosunki z partnerem handlowym podmioty AEO powinny zachęcać drugą stronę umowy do oceny i poprawy bezpieczeństwa wspólnego łańcucha dostaw. Ponadto zaleca się, by podmiot AEO zachował dokumentację potwierdzającą podejmowane przez niego wysiłki, mające na celu zapewnienie, że jego partnerzy handlowi spełniaja te wymogi - planowane jest wprowadzenie Deklaracji Bezpieczeństwa dla przedsiębiorstw nie posiadających statusu AEO. Podmiot AEO powinien także przeprowadzić przegląd właściwych informacji handlowych dotyczących drugiej strony umowy przed wejściem $\mathrm{z}$ nią w stosunki handlowe.

Jeżeli podmiot AEO posiada informację, że jeden $\mathrm{z}$ jego partnerów handlowych, wchodzący w skład międzynarodowego łańcucha dostaw nie 
wdrożył właściwych standardów bezpieczeństwa i ochrony, wówczas taki podmiot AEO podejmie niezwłocznie odpowiednie działania, w możliwym dla siebie do zrealizowania zakresie, w celu poprawy bezpieczeństwa łańcucha wartości.

W odniesieniu do przesyłek przejmowanych od nieznanych partnerów handlowych zaleca się, by podmiot AEO podjął działania gwarantujące, że ryzyko dla bezpieczeństwa związane z nieznanym partnerem handlowym zostanie ograniczone do możliwego do przyjęcia poziomu. W wypadku odkrycia przez AEO trudności $\mathrm{w}$ spełnieniu przepisów, podmiot AEO kontaktuje się z organami celnymi i powiadamia je o takich wypadkach.

\section{Podsumowanie}

Inwestycje dokonane przez podmioty gospodarcze wchodzące w skład logistycznego łańcucha dostaw $\mathrm{w}$ celu poprawy ich standardów bezpieczeństwa i ochrony, w związku z chęcią posiadania statusu AEO, mogą przynieść pozytywne efekty w następujących obszarach:

- kontroli nad przepływem towarów od producenta do konsumenta (,visibility and tracking”);

- opracowywania procedur postępowania;

- zaangażowania pracowników w procedury;

- wyboru dostawców i inwestycji;

- bezpieczeństwa transportu i przewozów;

- budowania świadomości infrastruktury organizacyjnej;

- współpracy między stronami łańcucha dostaw;

- aktywnych inwestycji technologicznych oraz dobrowolnego przestrzegania wymogów bezpieczeństwa;

- liczby wypadków związanych z bezpieczeństwem i ochroną;

- bezpieczeństwa i komunikacji pomiędzy partnerami w łańcuchu dostaw.

Ponieważ wprowadzono dwuletni okres przejściowy (01.01.2008 31.12.2009), w którym czas oczekiwania na rozpatrzenie wniosku wydłużono do 300 dni kalendarzowych, w momencie pisania artykułu nie uzyskano informacji o żadnym podmiocie gospodarczym w Polsce posiadającym status AEO. Celowa jest dalsza obserwacja przebiegu certyfikacji AEO oraz wynikających z niej korzyści. 
